\title{
Simulation of the size-composition distribution of atmospheric nanoparticles over Europe
}

\author{
David Patoulias $^{1,2}$, Christos Fountoukis ${ }^{2,3}$, Ilona Riipinen ${ }^{4,5}$, Ari Asmi ${ }^{6}$, Markku Kulmala ${ }^{6}$, and Spyros N. Pandis ${ }^{1,2,7}$ \\ ${ }^{1}$ Department of Chemical Engineering, University of Patras, Patras, Greece \\ ${ }^{2}$ Institute of Chemical Engineering Sciences, Foundation for Research and Technology - Hellas (FORTH/ICE-HT), \\ Patras, Greece \\ ${ }^{3}$ Qatar Environment \& Energy Research Institute, Hamad Bin Khalifa University, Doha, Qatar \\ ${ }^{4}$ Department of Environmental Science and Analytical Chemistry (ACES) and Bolin Centre for Climate Research, \\ Stockholm University, Stockholm, Sweden \\ ${ }^{5}$ Aerosol Physics, Faculty of Science, Tampere University of Technology, Tampere, Finland \\ ${ }^{6}$ Institute for Atmospheric and Earth System Research/Physics, Faculty of Science, P.O. Box 64, 00014, \\ University of Helsinki, Helsinki, Finland \\ ${ }^{7}$ Department of Chemical Engineering, Carnegie Mellon University, Pittsburgh, PA 15213, USA
}

Correspondence: Spyros N. Pandis (spyros@chemeng.upatras.gr)

Received: 24 January 2018 - Discussion started: 26 March 2018

Revised: 28 July 2018 - Accepted: 28 August 2018 - Published: 27 September 2018

\begin{abstract}
PMCAMx-UF, a three-dimensional chemical transport model focusing on the simulation of the ultrafine particle size distribution and composition has been extended with the addition of the volatility basis set (VBS) approach for the simulation of organic aerosol (OA). The model was applied in Europe to quantify the effect of secondary semivolatile organic vapors on particle number concentrations. The model predictions were evaluated against field observations collected during the PEGASOS 2012 campaign. The measurements included both ground and airborne measurements, from stations across Europe and a zeppelin measuring above Po Valley. The ground level concentrations of particles with a diameter larger than $100 \mathrm{~nm}\left(N_{100}\right)$ were reproduced with a daily normalized mean error of $40 \%$ and a daily normalized mean bias of $-20 \%$. PMCAMx-UF tended to overestimate the concentration of particles with a diameter larger than $10 \mathrm{~nm}\left(N_{10}\right)$ with a daily normalized mean bias of $75 \%$. The model was able to reproduce, within a factor of $2,85 \%$ of the $N_{10}$ and $75 \%$ of the $N_{100}$ zeppelin measurements above ground. The condensation of organics led to an increase (50\%-120\%) in the $N_{100}$ concentration mainly in central and northern Europe, while the $N_{10}$ concentration decreased by $10 \%-30 \%$. Including the VBS in PMCAMx-UF improved its ability to simulate aerosol number concentra-
\end{abstract}

tion compared to simulations neglecting organic condensation on ultrafine particles.

\section{Introduction}

New particles are introduced in the atmosphere by two major processes: direct emission from multiple sources and nucleation from low-volatility vapors. Nucleation and subsequent growth of new particles have been observed in a variety of environments worldwide (Kulmala et al., 2004), representing a significant source of aerosol number. Fresh particles formed by nucleation can either be lost through coagulation with preexisting larger particles or grow through condensation of vapors (e.g., sulfuric acid, ammonia, organics, and nitric acid) to larger sizes (Adams and Seinfeld, 2002) and become cloud condensation nuclei $(\mathrm{CCN})$, thereby increasing the cloud droplet number concentration (Adams and Seinfeld, 2002). Thus, nucleation and subsequent growth by condensation can be an important source of CCN (Makkonen et al., 2009; Merikanto et al., 2009; Pierce and Adams, 2009; Wang and Penner, 2009; Yu and Luo, 2009). Considerable uncertainty arises from the partial understanding of the identity of the species involved in the growth of these nu- 
clei (Kulmala et al., 2004; Kerminen et al., 2012). Field measurements (Eisele and McMurry, 1997; Weber et al., 1998, 1999) and model simulations (Kulmala et al., 2000; Pirjola and Kulmala, 2001; Anttila and Kerminen, 2003) indicated that the condensation of sulfuric acid alone is often not sufficient to justify the observed growth rates of fresh particles (Riipinen et al., 2011). Organics dominate particle growth in a lot of environments, but sulfuric acid and ammonia also play an important role in sulfur-rich areas (Stanier et al., 2004; Yue et al., 2010). Growth of new particles has been attributed to the condensation of organic species (Kulmala et al., 1998; Anttila and Kerminen, 2003; Kerminen et al., 2000), heterogeneous reactions (Zhang and Wexler, 2002), or ion-enhanced condensation (Laakso et al., 2002).

Secondary organic aerosol (SOA) comprises a major mass fraction $(20 \%-90 \%)$ of sub-micrometer particulate matter in many locations around the globe (Jimenez et al., 2009). Even though organic aerosol (OA) has been the subject of numerous studies (Hallquist et al., 2009), its chemical composition remains uncertain, making it one of the least understood components of atmospheric aerosols due to the large number of different atmospheric organic compounds (Goldstein and Galbally, 2007).

Atmospheric OA composition continuously evolves with time as a result of various chemical reactions (Kanakidou et al., 2005). The semi-volatile products which are produced from the gas-phase oxidation of volatile organic compounds (VOCs) can afterwards condense to the particulate phase. The volatility basis set (VBS) framework describes the volatility distribution of OA compounds (Donahue et al., 2006) using logarithmically spaced bins of the effective saturation concentration, $C^{*}\left(\mu \mathrm{g} \mathrm{m}^{-3}\right)$ at $298 \mathrm{~K}$, to classify atmospheric organic species. This framework has been tested in three-dimensional regional (3-D) chemical transport models (CTMs) and appears to perform well for simulations of aerosol mass distributions (Gaydos et al., 2007; Karydis et al., 2007; Murphy and Pandis, 2009; Tsimpidi et al., 2010; Fountoukis et al., 2011, 2014).

A new 3-D CTM, PMCAMx-UF, with detailed aerosol microphysics was developed by Jung et al. (2010) and has been used for simulations over the US and Europe (Fountoukis et al., 2012; Baranizadeh et al., 2016). For the US domain, the first comparison of the model and the measurements in Pittsburgh was encouraging; this evaluation focused on the frequency, timing, and strength of nucleation events (Jung et al., 2010). Applications in Europe compared model predictions against size distribution measurements from seven sites (Fountoukis et al., 2012). The model was capable of reproducing more than $70 \%$ of the hourly number concentrations of particles larger than $10 \mathrm{~nm}\left(N_{10}\right)$ within a factor of 2. However, the concentration of particles larger than $100 \mathrm{~nm}\left(N_{100}\right.$, the number of particles that can act as $\left.\mathrm{CCN}\right)$ was underpredicted by $50 \%$. Even at sites where the sulfateto-OA mass ratio was high (e.g., Melpitz), the nanoparticle growth rates were underpredicted, but with smaller errors compared with sites with relatively less sulfate. These problems were caused mainly by insufficient organic vapor condensation (Fountoukis et al., 2012), as the model did not explicitly include SOA condensation on particles. Based on observations from two background sites, Riipinen et al. (2011) estimated that roughly half of the condensed organic mass should contribute to nanoparticle growth in order to explain the observed aerosol growth rates.

Patoulias et al. (2015) developed a new aerosol dynamic model, DMANx (Dynamic Model for Aerosol Nucleation extended), that simulates aerosol size and composition distribution and includes the condensation of organic vapors on nanoparticles using the VBS framework. Simulations were performed for the sites of Hyytiälä (Finland) and Finokalia (Greece): two locations with different organic sources. Patoulias et al. (2015) investigated the effect of condensation of organics and chemical aging reactions of SOA precursors on ultrafine particle growth and particle number concentration during a typical springtime nucleation event at both locations. At the Finokalia site, the simulations suggested that the organics play a complementary role in new particle growth, contributing $45 \%$ to the total mass of new particles. Condensation of organics increased the $N_{100}$ by $13 \%$ at Finokalia and $25 \%$ at Hyytiälä during a typical spring day with nucleation.

The overall objective of this work is to examine the effect of the condensation of secondary organic vapors (products of the oxidation of VOCs and of the intermediate-volatility organic compounds, IVOCs) on particle number concentrations. Our hypothesis is that simulation of the corresponding interactions improves the ability of CTMs to reproduce ambient observations of the aerosol number distribution. Organic condensation can play a much more complex role than simply helping in the ultrafine particle growth. It increases the condensational and coagulation sinks, thus reducing nucleation rates and increasing coagulation rates. Given the complexity and the nonlinearity of these interactions, the net effect of organic condensation on particle number concentrations is by no means obvious.

We extended the 3-D CTM PMCAMx-UF (Fountoukis et al., 2012; Jung et al., 2010), which originally assumed that ultrafine particles can grow only by condensation of sulfuric acid and ammonia as well as by coagulation. The updated version of PMCAMx-UF includes the condensation of organic vapors on ultrafine particles using the VBS framework. We evaluated the model by comparing its predictions to surface-based high-time-resolution measurements from 16 stations in Europe and airborne measurements from the PEGASOS zeppelin campaign over the Po Valley in Italy.

\section{Model description}

PMCAMx-UF is a three-dimensional CTM that simulates the aerosol number size distribution, in addition to the mass 
and composition size distribution (Jung et al., 2010; Fountoukis et al., 2012). PMCAMx-UF is based on the framework of PMCAMx (Gaydos et al., 2007; Karydis et al., 2007), describing the processes of horizontal and vertical advection, emissions, horizontal and vertical dispersion, wet and dry deposition, aqueous and aerosol phase chemistry, and aerosol dynamics. For the simulation of aerosol microphysics, PMCAMx-UF uses the updated DMANx model of Patoulias et al. (2015), which simulates the processes of coagulation, condensation and evaporation, and nucleation, assuming an internally mixed aerosol. DMANx uses the TwoMoment Aerosol Sectional (TOMAS) algorithm (Adams and Seinfeld, 2002; Jung et al., 2006). A key feature of TOMAS is its ability to track two independent moments of the aerosol size distribution for each size bin: the aerosol number and mass concentration. The aerosol size distribution is described with 41 size sections with the lowest boundary at $3.75 \times$ $10^{-25} \mathrm{~kg}$ of dry aerosol mass per particle. That corresponds approximately to a dry diameter of $0.8 \mathrm{~nm}$. The particle density in each bin is calculated and updated continuously as a function of the corresponding composition. Each successive boundary has double the mass of the previous one to facilitate the simulation of coagulation (Tzivion et al., 1987, 1989).

The particle components modeled include sulfate, ammonium, nitrate, sodium, chloride, crustal material, water $\left(\mathrm{H}_{2} \mathrm{O}\right)$, elemental carbon $(\mathrm{EC})$, primary organic aerosol (POA), and four SOA components. The TOMAS algorithm simulates the evaporation and condensation of sulfuric acid $\left(\mathrm{H}_{2} \mathrm{SO}_{4}\right)$, ammonia $\left(\mathrm{NH}_{3}\right)$, and organics independently.

\subsection{Nucleation parameterizations}

PMCAMx-UF has the option of using a number of nucleation treatments (Fountoukis et al., 2012; Baranizadeh et al., 2016). In this work, the nucleation rate was calculated using a scaled ternary nucleation parameterization based on the original expressions of Napari et al. (2002) and the binary parameterization of Vehkamäki et al. (2002), if the $\mathrm{NH}_{3}$ concentration was below a threshold value of $0.01 \mathrm{ppt}$. The original $\mathrm{NH}_{3}-\mathrm{H}_{2} \mathrm{SO}_{4}-\mathrm{H}_{2} \mathrm{O}$ parameterization had successfully predicted the presence or lack of nucleation events (Gaydos et al., 2005) in sulfur-rich environments. However, it overpredicted ultrafine number concentrations during nucleation events (Fountoukis et al., 2012; Jung et al., 2008, 2010), and thus a scaling factor of $10^{-6}$ was applied to the nucleation rate following the suggestions of Fountoukis et al. (2012). The critical nucleus is assumed to consist of roughly two molecules of sulfuric acid and two molecules of ammonia, consistent with its assumed size (Napari et al., 2002).

\subsection{Gas-phase chemistry}

The gas-phase chemistry mechanism in PMCAMx-UF was updated in this work to the SAPRC chemical mechanism (Carter, 2000; Environ, 2003), which includes 211 reactions of 56 gases and 18 free radicals. The SAPRC version used here includes five lumped alkanes (ALK1-5), two lumped olefins (OLE1-2), two lumped aromatics (ARO1-2), isoprene (ISOP), a lumped monoterpene (TERP) and a lumped sesquiterpene species (SESQ). OLE1 contains all the terminal alkenes, while OLE2 represents all the internal and cyclic alkenes. All lumped VOCs with the exception of ALK1-3 are considered to be SOA precursors (Lane et al., 2008a, b; Tsimpidi et al., 2010).

\subsection{Coagulation}

Coagulation of particles in the atmosphere is an important sink of aerosol number, but it is also a mechanism by which freshly nucleated particles grow to larger sizes (Adams and Seinfeld, 2002). The TOMAS algorithm is used for the simulation of coagulation. Following Adams and Seinfeld (2002), TOMAS assumes that the particles coagulate via Brownian diffusion and the effects of gravitational settling and turbulence are neglected.

\subsection{Particle number and mass emissions}

The particle emissions were based on the pan-European anthropogenic particle number emission inventory (Denier van der Gon et al., 2009; Kulmala et al., 2011) and the carbonaceous aerosol inventory (Kulmala et al., 2011) developed during the EUCAARI (European Integrated project on Aerosol, Cloud, Climate, and Air Quality Interactions) project. The resulting number and mass inventory includes both number emissions and consistent size-resolved composition for particles over the size range of $10 \mathrm{~nm}$ to $10 \mu \mathrm{m}$. Hourly gridded anthropogenic and biogenic emissions included both gases and primary particulate matter. The natural emissions include both particulate matter and gases and combine three different datasets: emissions from ecosystems based on the Model of Emissions of Gases and Aerosols from Nature (MEGAN; Guenther et al., 2006), marine emissions based on the model of O'Dowd et al. (2008), and wildfire emissions (Sofiev et al., 2008a, b). MEGAN uses the plant functional type, the leaf area index, various chemical species emission factors, and weather data provided by the Weather Research and Forecasting model (WRF) as input (Skamarock et al., 2005). Since sea surface covers a considerable portion of the domain, the marine aerosol emission model developed by O'Dowd et al. (2008) was also used. Wind speed fields from WRF and chlorophyll $a$ concentrations were used as inputs of the marine aerosol model. VOCs were speciated based on the approach proposed by Visschedijk et al. (2007). Anthropogenic gas emissions included land emissions from the GEMS (Global and regional Earth-system Monitoring using Satellite and in-situ data) dataset (Visschedijk et al., 2007). International shipping, industrial, domestic, agricultural, and traffic aerosol emission sources were included in 
the anthropogenic inventory (Denier van der Gon et al., 2009; Kulmala et al., 2011).

\subsection{Condensation and evaporation}

Condensation of gas-phase species to existing aerosol particles is an important source of aerosol mass and a means by which small particles grow to CCN sizes. The TOMAS algorithm was used for the simulation of condensation and evaporation of sulfuric acid, ammonia, and organic vapors, using the wet diameters of the particles (Gaydos et al., 2005).

Sulfuric acid is assumed to be in pseudo-steady state in DMANx. This pseudo-steady-state approximation (PSSA) for sulfuric acid proposed by Pierce and Adams (2009) increases the computational speed with a small loss in accuracy. Jung et al. (2010) evaluated the performance of PSSA for sulfuric acid in DMAN (Dynamic Model for Aerosol Nucleation) against a fourth-order Runge-Kutta algorithm and showed that PSSA was accurate and computationally efficient. Condensation of ammonia was simulated following the approach described by Jung et al. (2006). Ammonia condensation on the ultrafine particles ends when sulfate is fully neutralized to ammonium sulfate.

Nitric and hydrochloric acid partition to particles in the accumulation and coarse modes in PMCAMx-UF as nitrate and chloride, respectively. This partitioning is simulated using the bulk equilibrium approach. At each time step the amount of nitric acid and hydrochloric acid transferred between the gas and aerosol phases is determined by applying the aerosol thermodynamic equilibrium model ISORROPIA (Nenes et al., 1998). This amount is then distributed over the aerosol size distribution by using weighting factors for each size section based on their effective surface area (Pandis et al., 1993). This treatment ensures that the appropriate amount is transferred to the larger particles; however, it cannot accurately describe any potential transfer of these acids to the nucleation mode. This simplification dramatically reduces the computational burden with a minimal loss of accuracy since ultrafine particle growth is governed by low-volatility compounds.

\subsection{Secondary organic aerosol formation}

Gas-phase oxidation of VOCs produces semi-volatile products that can then condense to the particle phase. The VBS framework (Donahue et al., 2006) used in PMCAMx-UF describes the volatility distribution of OA compounds using logarithmically spaced bins, characterized by an effective saturation concentration, $C^{*}\left(\mu \mathrm{g} \mathrm{m}^{-3}\right)$. SOA components partition between the aerosol and gas phases and can be formed from anthropogenic (aSOA) and biogenic (bSOA) precursors. SOA partitioning was simulated using four volatility bins $\left(1-10^{3} \mu \mathrm{g} \mathrm{m}^{-3}\right.$ at $\left.298 \mathrm{~K}\right)$. We assume an average molecular weight of $200 \mathrm{~g} \mathrm{~mol}^{-1}$ for SOA and an effective enthalpy of vaporization of $30 \mathrm{~kJ} \mathrm{~mol}^{-1}$ (Pathak et al., 2007; Stanier et al., 2007). The partitioning of OA between

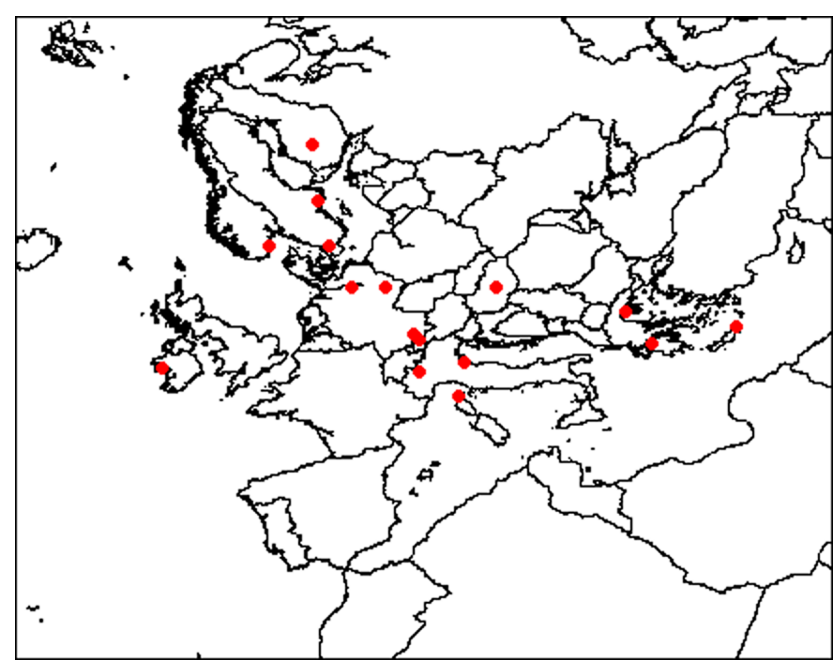

Figure 1. Modeling domain of PMCAMx-UF for Europe. Red dots show the measurement stations of Birkenes (Norway), Hyytiälä (Finland), K-puszta (Hungary), Aspvreten (Sweden), Vavihill (Sweden), Ispra (Italy), San Pietro Capofiume (Italy), Corsica (France), Patras (Greece), Finokalia (Greece), Thessaloniki (Greece), Mace Head (Ireland), Schneefernerhaus (Germany), Hohenpeissenberg (Germany), Melpitz (Germany), and Waldhof (Germany).

the gas and particulate phases is simulated dynamically (Patoulias et al., 2015).

The SOA yields used in the updated version of PMCAMxUF are based on the $\mathrm{NO}_{x}$-dependent yields of Murphy et al. (2009). The current work focuses on the effect of the formation of semi-volatile organic aerosol on particle number concentrations. The role of later-generation reactions (known as chemical aging) and also the formation of lowvolatility (LVOC) and extremely low-volatility organic compound (ELVOC) formation (Ehn et al., 2014; Tröstl et al., 2016) is rather complex and will be the topic of future work.

\subsection{Meteorological input fields}

Meteorological inputs to PMCAMx-UF included horizontal wind components, vertical diffusivity, temperature, pressure, water vapor, clouds, and rainfall. The meteorological model WRF (Skamarock et al., 2005) was used to create the above inputs. WRF was driven by geographical and dynamic meteorological data (historical data generated by the Global Forecast System). Each layer of PMCAMx-UF was aligned with the layers used in WRF. The WRF simulation was periodically re-initialized (every 3 days) with observed conditions to ensure accuracy in the corresponding fields that were used as inputs in PMCAMx-UF, for 34 days from 5 June to 8 July 2012. The 3-day re-initialization was chosen because of its simplicity and the fact that the corresponding WRF predictions remain consistent with all the measurements. The measurements are preprocessed by the WPS (WRF Preprocessing System) package, which provides each atmospheric 

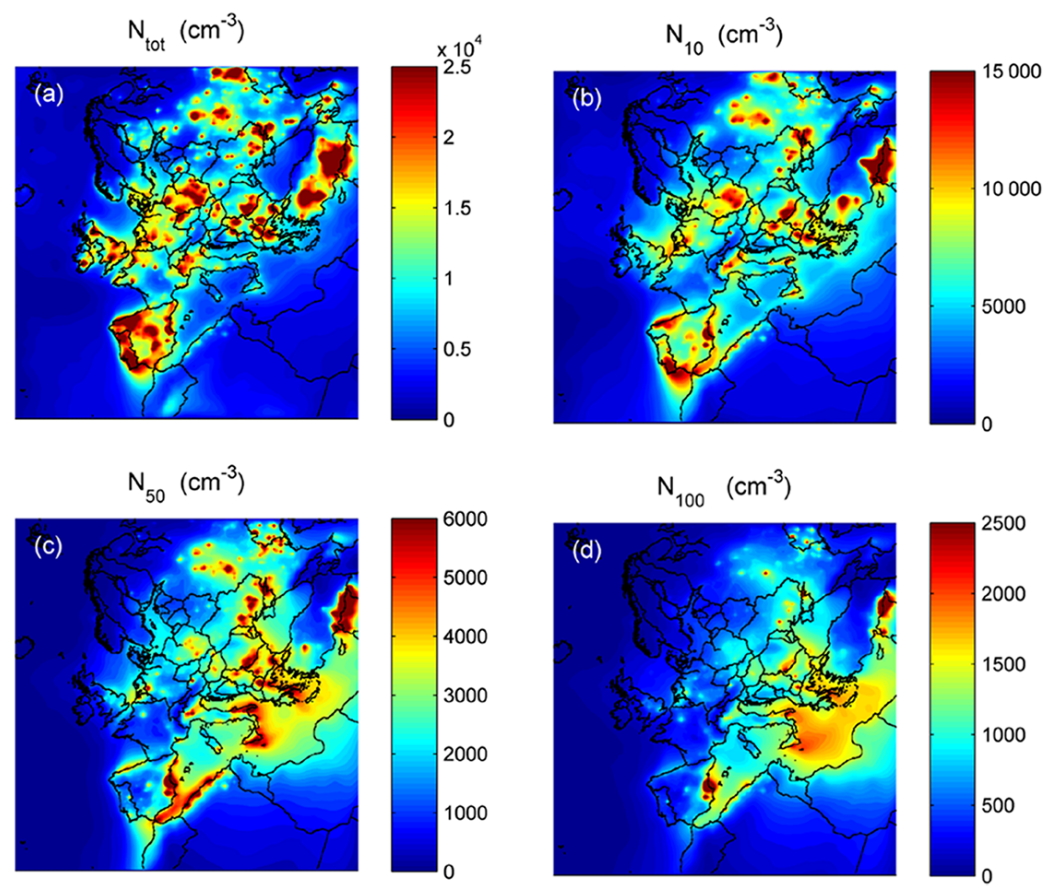

Figure 2. Ground-level average number concentrations $\left(\mathrm{cm}^{-3}\right)$ predicted by the base case simulation during 5 June-8 July 2012 for (a) all particles $\left(N_{\text {tot }}\right)$ and particles above (b) $10 \mathrm{~nm}\left(N_{10}\right)$, (c) $50 \mathrm{~nm}\left(N_{50}\right)$, and (d) $100 \mathrm{~nm}\left(N_{100}\right)$. Different color scales are used.

and static field with fidelity appropriate to the chosen grid resolution of the model. The performance of WRF for Europe against observed meteorological variables has been the topic of several studies (Jimenez-Guerrero et al., 2008; de Meij et al., 2009; Im et al., 2010; Argueso et al., 2011; Garcia-Diez et al., 2012) with all of them showing good performance.

\section{Model application and measurements}

The PMCAMx-UF modeling domain in this application covered a $5400 \times 5832 \mathrm{~km}^{2}$ region in Europe (Fig. 1), with 150 cells in the $x$ direction and 162 cells in the $y$ direction, with a $36 \times 36 \mathrm{~km}$ grid resolution and 14 vertical layers (the height of each layer can be found in the Supplement, Table S1) extending up to approximately $7.5 \mathrm{~km}$. PMCAMxUF was set to perform simulations on a rotated polar stereographic map projection.

The first 2 days of each simulation were excluded from the analysis to minimize the effect of the initial conditions on the results. The initial conditions affect the predictions for a period similar to the average residence time of the pollutants in the modeling domain. Given that this is a regional simulation, this period is significantly shorter than the lifetime of the particles in the atmosphere. Based on our tests 2 days are indeed sufficient for the model to "forget" the initial conditions and for emissions and chemistry to take over. The initial concentrations used are low to further decrease their impact on the results (Supplement, Table S2).
Constant very low values have been used for the boundary conditions (Table S2) so that the predicted particle number concentrations over Europe are determined for all practical purposes by the emissions and corresponding processes simulated by the model. The effect of these boundary conditions on the predicted number concentrations is discussed in a subsequent section.

An intensive field campaign took place in Europe, as part of the Pan-European Gas-AeroSOl-climate interaction Study (PEGASOS) project, for 34 days from 5 June to 8 July 2012. Measurements of aerosol size distribution from the Aerosols, Clouds, and Trace gases Research InfraStructure (ACTRIS) network, Chemistry-Aerosol Mediterranean Experiment (ChArMEx), and the German Ultrafine Aerosol Network (GUAN) network are also available for the same period. The model results were compared against measurements at ground sites (Fig. 1): Birkenes (Norway), Hyytiälä (Finland), Aspvreten (Sweden), Vavihill (Sweden), K-puszta (Hungary), Ispra (Italy), San Pietro Capofiume (Italy), Corsica (France), Patras (Greece), Finokalia (Greece), Thessaloniki (Greece), Mace Head (Ireland), Hohenpeissenberg (Germany), Melpitz (Germany), Waldhof (Germany), and Schneefernerhaus (Germany). The measurements are available in the EUropean Supersites for Atmospheric Aerosol Research (EUSAAR), ChArMEx (http://charmex.lsce.ipsl. fr/, last access: 12 September 2018), and EBAS databases (http://ebas.nilu.no/, last access: 12 September 2018). Particle size distribution measurements at all sites were made using either a differential mobility particle sizer (DMPS) or a 

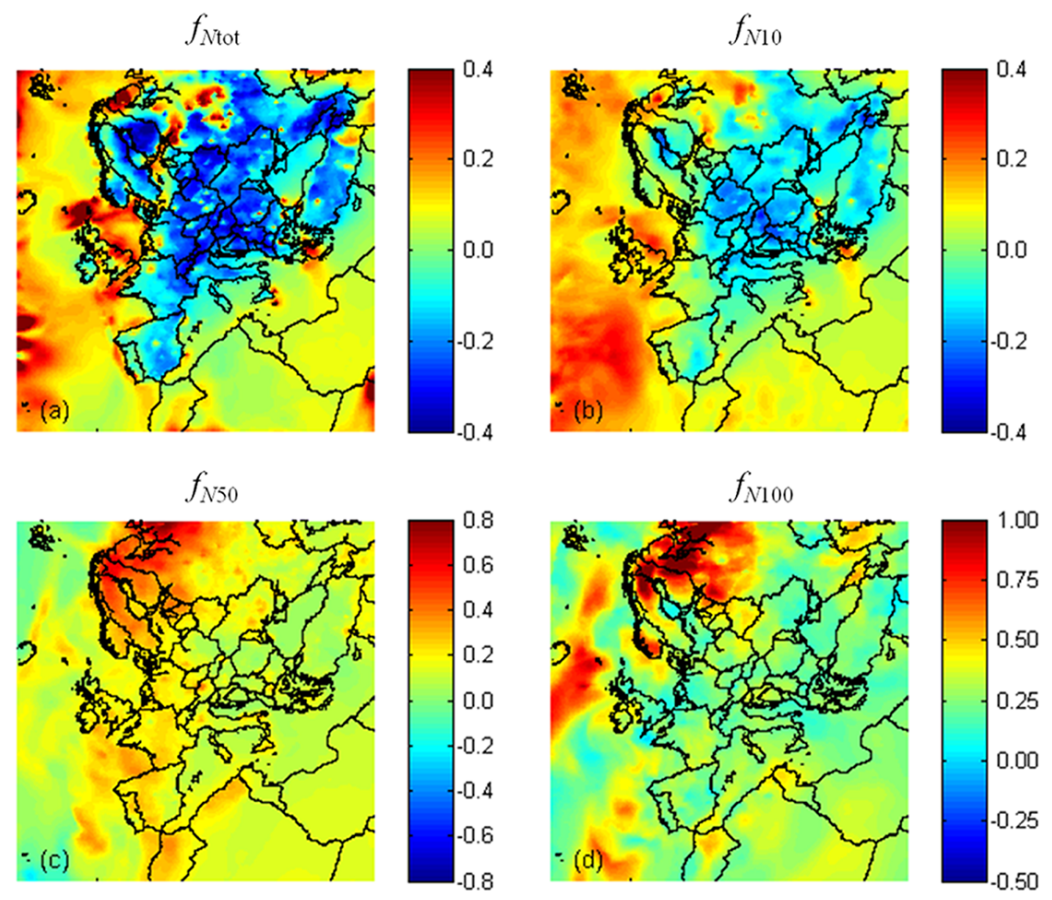

Figure 3. Ground-level average fractional increase $\left(f_{N_{x}}\right)$ in number concentration due to the condensation of organic species predicted during 5 June- 8 July for (a) all particles $\left(f_{N_{\text {tot }}}\right)$ and particles above (b) $10 \mathrm{~nm}\left(f_{N_{10}}\right)$, (c) $50 \mathrm{~nm}\left(f_{N_{50}}\right)$, and (d) $100 \mathrm{~nm}\left(f_{N_{100}}\right)$. Different scales are used.

scanning mobility particle sizer (SMPS). Information about all stations can be found in the Supplement (Sect. S1).

The airborne measurements acquired by a zeppelin were part of the PEGASOS project over the Po Valley in Italy. The Po Valley region is situated between the Alps in the north and the Apennine Mountains in the south-southwest. The mountains surround the valley on three sides and strongly modify both the local and regional air flow patterns in the area (Sogacheva et al., 2007). High levels of pollutants are often observed in the region due to the industrial, agricultural, and other anthropogenic emissions. In addition, the emissions from ship traffic on the Adriatic Sea (Hamed et al., 2007) and long-range transport from central-eastern Europe are possible sources of pollutants in the region (Sogacheva et al., 2007). A SMPS was used to measure the number size distribution of particles in the size range of 10 to $430 \mathrm{~nm}$.

\section{Results}

\subsection{Base case simulation}

Figure 2 shows the base case PMCAMx-UF predictions of ground-level average number concentration for all particles $\left(N_{\text {tot }}\right)$ and for particles with diameters above $10 \mathrm{~nm}$ $\left(N_{10}\right), 50 \mathrm{~nm}\left(N_{50}\right)$, and $100 \mathrm{~nm}\left(N_{100}\right)$, during 5 June to 8 July 2012 (34 days). The $N_{50}$ and $N_{100}$ concentrations are often used as proxies for $\mathrm{CCN}$-related aerosol number concentrations (Fountoukis et al., 2012). The $N_{10}$ can be directly compared against the DMPS or SMPS measurements. On a domain average basis, the model predicted, for the ground level, $N_{\text {tot }}=6500 \mathrm{~cm}^{-3}, N_{10}=3800 \mathrm{~cm}^{-3}, N_{50}=$ $1550 \mathrm{~cm}^{-3}$, and $N_{100}=520 \mathrm{~cm}^{-3}$ during the simulated period. High $N_{\text {tot }}$ and $N_{10}$ are predicted in areas with frequent nucleation events and also areas with high primary particle number emissions. Average $N_{\text {tot }}$ concentrations exceeding $20000 \mathrm{~cm}^{-3}$ were predicted over Bulgaria, Bosnia, southern Romania, Turkey, Germany, Poland, the Netherlands, Portugal, northern Spain, the eastern UK, northern Italy, and central Russia. Conversely, $N_{50}$ and $N_{100}$ are also affected by secondary particulate matter production. The highest $N_{50}$ and $N_{100}$ concentrations are predicted over the Mediterranean, mainly in areas near southern Spain, southern Italy, and Greece.

An additional simulation, without taking into account the condensation of organics, was also performed. The average fractional increase in $N_{x}, f_{N_{x}}$, due to the condensation of organic species is defined as

$f_{N_{x}}=\frac{N_{x} \text { (with organics) }-N_{x} \text { (without organics) }}{N_{x} \text { (without organics) }}$,

where $x$ is $10,50,100 \mathrm{~nm}$, or the total.

Predictions of $f_{N_{x}}$ are shown in Fig. 3. The average fractional changes are $-0.02,-0.05,0.15$, and 0.33 for $N_{\text {tot }}$, $N_{10}, N_{50}$, and $N_{100}$, respectively. The condensation of organics was predicted to decrease the total number concen- 
tration $N_{\text {tot }}$ over most of continental Europe. The largest decrease was approximately $50 \%$. This rather counterintuitive result is due to the increase in both the condensation and coagulation sinks as SOA is formed. These effects dominated over the faster growth of fresh nuclei or other nanoparticles to larger sizes that tend to slow down their coagulation rate and increase their lifetime. In the other extreme, an increase in $N_{\text {tot }}$ of approximately $60 \%$ was predicted over the eastern UK. In this area organic condensation does lead to higher number concentrations. The predicted $N_{10}$ also decreased between $15 \%$ and $30 \%$ due to organic condensation over most of Europe. The minimum value of $f_{N_{10}}$ was about -0.30 over Serbia, while the maximum $f_{N_{10}}$ was about 0.35 over the eastern UK. Conversely, the condensation of organics increased the $N_{50}$ over the whole domain. The increase was $40 \%-80 \%$ over Scandinavia and northern Russia. The condensation of semi-volatile organic vapors results in an increase in $N_{100}$ by $70 \%-150 \%$ over northern Scandinavia and northwestern Russia according to PMCAMx-UF.

The absolute increase in particle number concentration $\left(\Delta N_{x}\right)$ due to the organic condensation is defined as

$$
\Delta N_{x}=N_{x} \text { (with organics) }-N_{x} \text { (without organics), }
$$

where $x$ is $10,50,100 \mathrm{~nm}$, or the total.

$N_{\text {tot }}$ decreased over Turkey, central and eastern Europe, and the Balkans by 2000 to $5000 \mathrm{~cm}^{-3}$ while it increased over the eastern UK by roughly $3000 \mathrm{~cm}^{-3}$ (Fig. S1). The highest reduction of $N_{\text {tot }}$ was approximately $15000 \mathrm{~cm}^{-3}$ over Hungary and central Turkey. The predicted $\Delta N_{10}$ over central Europe was in the range of -1000 to $-3000 \mathrm{~cm}^{-3}$. The maximum reduction of $N_{10}$ was equal to $3600 \mathrm{~cm}^{-3}$ over Hungary while its maximum increase was $6500 \mathrm{~cm}^{-3}$ over the eastern UK. The $N_{50}$ increased due to the condensation of organics over Italy, central Russia, the Netherlands, Ukraine, the eastern Mediterranean, the coast of Algeria, and Spain by $500-2000 \mathrm{~cm}^{-3} . N_{100}$ increased from 300 to $800 \mathrm{~cm}^{-3}$ over the Mediterranean and southern Russia. The maximum $N_{100}$ increase was about $2000 \mathrm{~cm}^{-3}$ over Malta and southern Italy. The corresponding changes of the concentrations of particles with diameters between 10 and $50 \mathrm{~nm}\left(N_{10-50}\right)$ and between 50 and $100 \mathrm{~nm}\left(N_{10-50}\right)$ are shown in Fig. S2.

\subsection{Evaluation of extended PMCAMx-UF}

The predicted daily average concentrations of particles larger than 10,50 , and $100 \mathrm{~nm}$ are compared to the corresponding observations at all ground stations in Fig. 4. Around $65 \%$ of the observed $N_{10}$ observations were reproduced within a factor of 2 by PMCAMx-UF, with the model tending to overestimate the corresponding concentrations. The model performed even better for $N_{50}$, reproducing $80 \%$ of the measurements within a factor of 2. PMCAMx-UF presented a tendency to underestimate the $N_{100}$ levels but still reproduced $70 \%$ of the data within a factor of 2 . The model does a good job in capturing the observed variability in all size
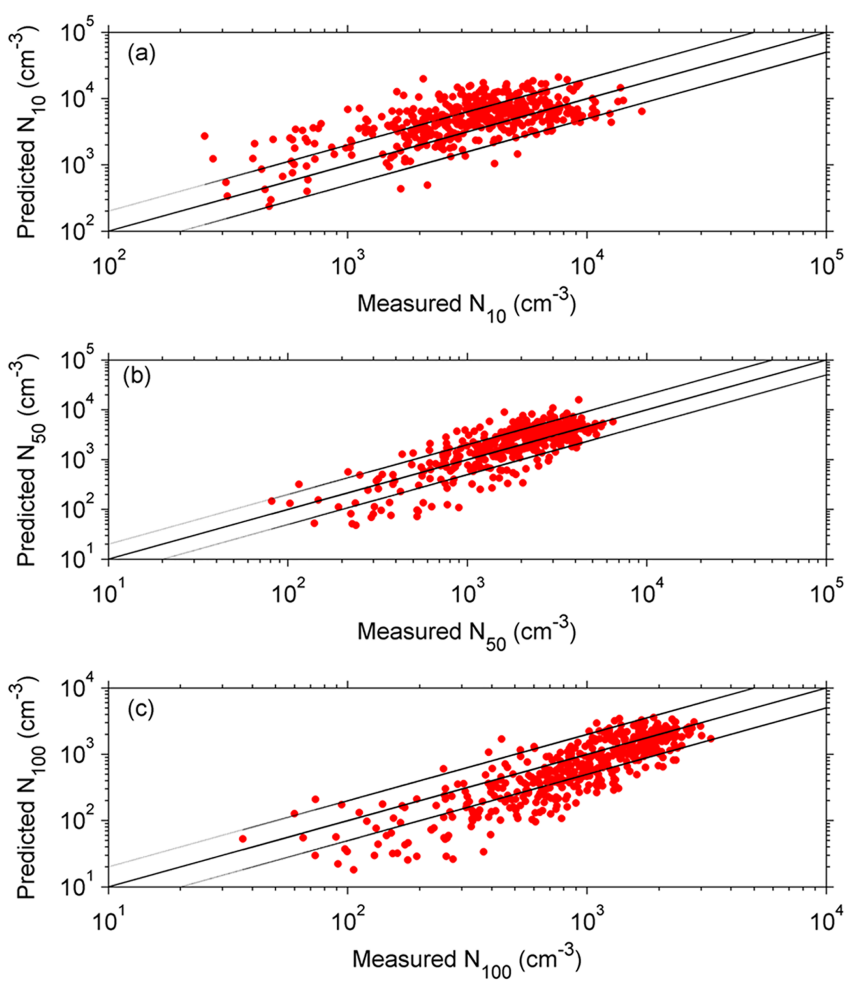

Figure 4. Comparison of predicted versus observed particle number concentrations $\left(\mathrm{cm}^{-3}\right)$ above 10,50 , and $100 \mathrm{~nm}$ from the 16 measurement stations across Europe during 5 June-8 July 2012. Each point corresponds to a daily average value. Also shown are the $1: 1$, $2: 1$, and $1: 2$ lines.

ranges and also appears to reproduce the observations at the low concentration levels.

The prediction skill metrics of PMCAMx-UF, when compared against the daily average measurements from the 16 stations, are summarized in Tables 1-3. The average normalized mean error (NME) for $N_{10}$ was $90 \%$ and the normalized mean bias (NMB) was $75 \%$. The $N_{10}$ was overestimated in most locations with the exception of Hyytiälä, San Pietro Capofiume, and Hohenpeissenberg. The NMB was less than $30 \%$ in K-puszta, Melpitz, and Patras. The model really overpredicted $N_{10}(\mathrm{NMB}>100 \%)$ at several stations in northern Europe (Aspvreten, Birkenes, Vavihill), some coastal locations (Corsica and Mace Head), two German sites (Waldhof and Schneefernerhaus), and the Thessaloniki site in northern Greece. The overall NMB and NME for $N_{50}$ were $25 \%$ and $50 \%$, respectively. The $N_{50} \mathrm{NMB}$ was less than $50 \%$ at 14 stations, with only Aspvreten and Thessaloniki being exceptions. At these 14 stations the corresponding error was less than $70 \%$. Finally, $N_{100}$ was underpredicted at all stations, with the exception of two Greek sites (Thessaloniki and Finokalia). However, this underprediction was less than $30 \%$ at 9 out of the 14 sites. Overall, the NMB for $N_{100}$ was $-20 \%$ and the NME for $N_{100}$ was $40 \%$ for the simulation with organics. 
Table 1. Prediction skill metrics of PMCAMx-UF against daily ground measurements of particle number concentration with a diameter above $10 \mathrm{~nm}$ from 16 stations during 5 June-8 July 2012.

\begin{tabular}{|c|c|c|c|c|c|c|c|}
\hline \multirow[t]{2}{*}{ Station } & \multirow[t]{2}{*}{$\begin{array}{r}\text { Mean } \\
\text { observed }\end{array}$} & \multicolumn{2}{|c|}{$\begin{array}{l}\text { Mean predicted } \\
\qquad\left(\mathrm{cm}^{-3}\right)\end{array}$} & \multicolumn{2}{|c|}{$\begin{array}{l}\text { Normalized mean } \\
\text { bias (NMB) }(\%)\end{array}$} & \multicolumn{2}{|c|}{$\begin{array}{l}\text { Normalized mean } \\
\text { error (NME) }(\%)\end{array}$} \\
\hline & & $\begin{array}{r}\text { With } \\
\text { organics }\end{array}$ & $\begin{array}{l}\text { Without } \\
\text { organics }\end{array}$ & $\begin{array}{r}\text { With } \\
\text { organics }\end{array}$ & $\begin{array}{l}\text { Without } \\
\text { organics }\end{array}$ & $\begin{array}{r}\text { With } \\
\text { organics }\end{array}$ & $\begin{array}{l}\text { Without } \\
\text { organics }\end{array}$ \\
\hline \multicolumn{8}{|l|}{$N_{10}$} \\
\hline ASP & 2090 & 5533 & 5496 & 165 & 163 & 165 & 163 \\
\hline BIR & 1937 & 4950 & 4608 & 156 & 138 & 160 & 143 \\
\hline COR & 2994 & 6768 & 7455 & 126 & 149 & 126 & 149 \\
\hline FIN & 3932 & 6091 & 6191 & 55 & 57 & 57 & 60 \\
\hline $\mathrm{HOH}$ & 3809 & 3801 & 4155 & 0 & 9 & 36 & 40 \\
\hline HYY & 2616 & 2239 & 2408 & -14 & -8 & 33 & 35 \\
\hline ISP & 6307 & 10481 & 11420 & 66 & 81 & 78 & 91 \\
\hline KPU & 5245 & 6686 & 8581 & 27 & 64 & 56 & 82 \\
\hline MAC & 822 & 1965 & 1758 & 139 & 114 & 149 & 135 \\
\hline MEL & 6045 & 7325 & 8680 & 21 & 44 & 60 & 75 \\
\hline PAT & 4858 & 5333 & 5449 & 10 & 12 & 50 & 53 \\
\hline $\mathrm{SCH}$ & 1286 & 2913 & 3279 & 127 & 155 & 127 & 155 \\
\hline SPC & 8319 & 7398 & 8547 & -11 & 3 & 34 & 33 \\
\hline THE & 4022 & 9755 & 10334 & 143 & 157 & 143 & 160 \\
\hline VAV & 3230 & 7561 & 7601 & 134 & 135 & 136 & 137 \\
\hline WAL & 5036 & 8194 & 8852 & 63 & 76 & 74 & 85 \\
\hline All & 3909 & 6062 & 6551 & 75 & 85 & 90 & 100 \\
\hline
\end{tabular}

Figures 5 and S3-S5 show measured and predicted average diurnal profiles of $N_{10}$. In Hyytiälä, Patras, and Hohenpeissenberg, the observed diurnal profiles of $N_{10}$ were flat, and the predicted diurnal profiles of $N_{10}$ were close to the observations. In Melpitz and San Pietro Capofiume, the observed and predicted $N_{10}$ increased at noon due to nucleation. In K-puszta, Ispra, Birkenes, Aspvreten, Vavihill, Thessaloniki, Schneefernerhaus, Finokalia, Corsica, and Waldhof, the model overpredicted $N_{10}$.

One of the potential explanations for the overprediction of $N_{10}$ is the corresponding overprediction in the frequency of nucleation. Figure 6 shows the predicted and measured nucleation frequency for the 16 stations during the 34 simulation days. The criteria proposed by Dal Maso et al. (2005) were used for the categorization of a day as a nucleation event. The nucleation frequency was defined as the ratio of the number of days characterized as nucleation events to the total number of days.

The observed nucleation frequency varied dramatically at the 16 sites from over $90 \%$ in San Pietro Capofiume to less than $10 \%$ in Patras. PMCAMx-UF reproduced this wide range (Fig. 6) with the predicted nucleation frequency being within $20 \%$ of the observed one in 12 out of the 16 stations. The model tends to overpredict nucleation frequency with the most significant errors at two coastal stations in the Mediterranean (Corsica and Patras) and two stations in Scandinavia (Birkenes and Aspvreten). This suggests that overpredicted nucleation frequency can explain part of the $N_{10}$ overprediction in at least three (Corsica, Birkenes, and Aspvreten) out of the eight stations.

The overprediction of $N_{10}$ could be also due to the low surface area of the particles, resulting in lower condensation and coagulation rates. The capability of the existing aerosol population to remove vapors and freshly formed particles can be described by the condensational sinks (Dal Maso et al., 2005). The model underpredicted the measured the condensational sink at most of the sites. In Corsica the model overpredicted the condensation sink, while in Thessaloniki, Birkenes, and Aspvreten the model is in good agreement with the measurements (Fig. 7). Summarizing, the errors in $N_{10}$ are caused by the high predicted nucleation rate at Aspvreten, Birkenes, Schneefernerhaus, Thessaloniki, and Vavihill and they are, at least partially, due to low predicted condensation sink at Ispra, K-Puszta, Mace Head and Melpitz. At Corsica, the overprediction of $N_{10}$ is due to errors in both the predicted nucleation rates and the condensation sink.

The average diurnal profiles of $N_{100}$ for all sites are shown in Figs. 8 and S6-S8. The model satisfactorily reproduced the average of $N_{100}$ observed in the Mediterranean (Corsica, San Pietro Capofiume, Patras, and Finokalia), with the exception of Thessaloniki, where PMCAMx-UF overestimated $N_{100}$ for most hours of the day.

In northern Europe, the predicted $N_{100}$ was in general below the observed $N_{100}$. The maximum underprediction of 
Table 2. Prediction skill metrics of PMCAMx-UF against daily ground measurements of particle number concentration with a diameter above $50 \mathrm{~nm}$ from 16 stations during 5 June-8 July 2012.

\begin{tabular}{|c|c|c|c|c|c|c|c|}
\hline \multirow[t]{2}{*}{ Station } & \multirow[t]{2}{*}{$\begin{array}{r}\text { Mean } \\
\text { observed }\end{array}$} & \multicolumn{2}{|c|}{$\begin{array}{l}\text { Mean predicted } \\
\qquad\left(\mathrm{cm}^{-3}\right)\end{array}$} & \multicolumn{2}{|c|}{$\begin{array}{l}\text { Normalize mean } \\
\text { bias (NMB) }(\%)\end{array}$} & \multicolumn{2}{|c|}{$\begin{array}{l}\text { Normalized mean } \\
\text { error (NME) }(\%)\end{array}$} \\
\hline & & $\begin{array}{r}\text { With } \\
\text { organics }\end{array}$ & $\begin{array}{l}\text { Without } \\
\text { organics }\end{array}$ & $\begin{array}{r}\text { With } \\
\text { organics }\end{array}$ & $\begin{array}{l}\text { Without } \\
\text { organics }\end{array}$ & $\begin{array}{r}\text { With } \\
\text { organics }\end{array}$ & $\begin{array}{l}\text { Without } \\
\text { organics }\end{array}$ \\
\hline \multicolumn{8}{|l|}{$N_{50}$} \\
\hline ASP & 1353 & 2419 & 1835 & 79 & 36 & 81 & 47 \\
\hline BIR & 1046 & 1364 & 1111 & 30 & 6 & 61 & 53 \\
\hline COR & 2460 & 3155 & 2883 & 28 & 17 & 41 & 37 \\
\hline FIN & 3085 & 4163 & 3905 & 35 & 27 & 39 & 32 \\
\hline $\mathrm{HOH}$ & 1988 & 1550 & 1340 & -22 & -33 & 31 & 35 \\
\hline HYY & 1546 & 1092 & 829 & -29 & -46 & 40 & 49 \\
\hline ISP & 3500 & 5399 & 4728 & 54 & 35 & 70 & 56 \\
\hline KPU & 2955 & 3674 & 3424 & 24 & 16 & 30 & 25 \\
\hline MAC & 489 & 315 & 278 & -36 & -43 & 70 & 67 \\
\hline MEL & 2243 & 2197 & 1824 & -2 & -19 & 23 & 24 \\
\hline PAT & 3249 & 3211 & 2983 & -1 & -8 & 29 & 28 \\
\hline $\mathrm{SCH}$ & 839 & 1202 & 1053 & 43 & 26 & 65 & 54 \\
\hline SPC & 3235 & 3686 & 3300 & 14 & 2 & 29 & 23 \\
\hline THE & 2334 & 5147 & 4545 & 120 & 95 & 120 & 95 \\
\hline VAV & 1628 & 2192 & 1812 & 35 & 11 & 45 & 33 \\
\hline WAL & 2050 & 2295 & 1882 & 12 & -8 & 22 & 16 \\
\hline All & 2125 & 2691 & 2358 & 25 & 10 & 50 & 40 \\
\hline
\end{tabular}

$N_{100}$ was observed in Hyytiälä, Mace Head, and Melpitz. This indicated that the concentration of large particles was lower than observed, and therefore the condensation sink was also lower (Fig. 7). This underprediction is probably due to a combination of lower primary particle emissions and lower growth rates of the particles. The PMCAMx-UF predictions for Hyytiälä and Mace Head are also quite sensitive to the boundary conditions used. Underestimation of the corresponding values could contribute to the $N_{100}$ underpredictions in these locations. The low prediction of organic aerosol causes the underprediction of $N_{100}$ in Patras and San Pietro Capofiume.

\subsection{Comparison to aerosol composition measurements}

The PMCAMx-UF predictions can be evaluated during that period using available $\mathrm{PM}_{1}$ measurements from aerosol mass spectrometers at four stations (Bologna and San Pietro Capofiume in Italy and Finokalia and Patras in Greece) and filter $\mathrm{PM}_{2.5}$ measurements from 12 additional stations in $\mathrm{Eu}-$ rope (Table $\mathrm{S} 3$ ).

In Italy and Greece, the model reproduces the observations of inorganic aerosol components (sulfate, nitrate, ammonium) reasonably well (e.g., errors in the average concentrations of less than $0.5 \mu \mathrm{g} \mathrm{m}^{-3}$ at the Italian sites), but it tends to underpredict the organic aerosol concentrations (Table S4). For example, the OA in San Pietro Capofiume is underpredicted by $40 \%$. This underprediction of the organics is the major reason for the underprediction of the condensational sink shown in Fig. 7 and is probably due to our assumptions about the chemical aging of the anthropogenic SOA. Based on previous work with the sister model PMCAMx (Fountoukis et al., 2011, 2014) in Europe, the chemical aging processes, which are not simulated in this version of PMCAMx-UF, should be able to explain a significant fraction of the missing OA. The role of these processes, the detailed evaluation of $\mathrm{PMCAMx} \mathrm{PM}_{1}$ mass and composition predictions during the PEGASOS campaigns, and the sensitivity of the model to chemical aging parameterizations are the main topics of ongoing work.

For the rest of Europe we have used measurements available in the European Supersites for Atmospheric Aerosol Research (EUSAAR) and EBAS databases (http://ebas.nilu.no/, last access: 12 September 2018) for stations that had available data for more than 15 days during the simulation period. Concerning the inorganic components, the model reproduced the sulfate measurements within $0.5 \mu \mathrm{g} \mathrm{m}^{-3}(\mathrm{Ta}-$ ble S6). However, it has a tendency to overestimate the ammonium nitrate levels and to underestimate the OA concentration. For the calculation of organic mass concentration, we assumed OA / OC = 1.4 (Russell, 2003). 
Table 3. Prediction skill metrics of PMCAMx-UF against daily ground measurements of particle number concentration with a diameter above $100 \mathrm{~nm}$ from 16 stations during 5 June-8 July 2012.

\begin{tabular}{|c|c|c|c|c|c|c|c|}
\hline \multirow[t]{2}{*}{ Station } & \multirow[t]{2}{*}{$\begin{array}{r}\text { Mean } \\
\text { observed }\end{array}$} & \multicolumn{2}{|c|}{$\begin{array}{l}\text { Mean predicted } \\
\qquad\left(\mathrm{cm}^{-3}\right)\end{array}$} & \multicolumn{2}{|c|}{$\begin{array}{l}\text { Normalize mean } \\
\text { bias (NMB) }(\%)\end{array}$} & \multicolumn{2}{|c|}{$\begin{array}{l}\text { Normalized mean } \\
\text { error (NME) }(\%)\end{array}$} \\
\hline & & $\begin{array}{r}\text { With } \\
\text { organics }\end{array}$ & $\begin{array}{l}\text { Without } \\
\text { organics }\end{array}$ & $\begin{array}{r}\text { With } \\
\text { organics }\end{array}$ & $\begin{array}{l}\text { Without } \\
\text { organics }\end{array}$ & $\begin{array}{r}\text { With } \\
\text { organics }\end{array}$ & $\begin{array}{l}\text { Without } \\
\text { organics }\end{array}$ \\
\hline \multicolumn{8}{|l|}{$N_{100}$} \\
\hline ASP & 540 & 372 & 343 & -31 & -37 & 45 & 46 \\
\hline BIR & 431 & 318 & 229 & -26 & -47 & 59 & 55 \\
\hline COR & 1304 & 1180 & 914 & -9 & -30 & 37 & 36 \\
\hline FIN & 1769 & 2002 & 1652 & 13 & -7 & 29 & 22 \\
\hline $\mathrm{HOH}$ & 911 & 558 & 448 & -40 & -50 & 43 & 51 \\
\hline HYY & 736 & 309 & 207 & -60 & -70 & 60 & 70 \\
\hline ISP & 1766 & 1461 & 1245 & -17 & -30 & 32 & 37 \\
\hline KPU & 1526 & 1486 & 1228 & -3 & -20 & 28 & 25 \\
\hline MAC & 242 & 116 & 86 & -50 & -64 & 60 & 65 \\
\hline MEL & 998 & 671 & 484 & -33 & -51 & 38 & 51 \\
\hline PAT & 1758 & 1471 & 1154 & -16 & -34 & 25 & 35 \\
\hline $\mathrm{SCH}$ & 496 & 442 & 360 & -11 & -27 & 43 & 36 \\
\hline SPC & 1667 & 1387 & 1132 & -17 & -32 & 31 & 37 \\
\hline THE & 1398 & 2020 & 1649 & 45 & 18 & 53 & 40 \\
\hline VAV & 749 & 438 & 358 & -41 & -52 & 46 & 54 \\
\hline WAL & 924 & 577 & 464 & -38 & -50 & 39 & 50 \\
\hline All & 1076 & 926 & 747 & -20 & -40 & 40 & 45 \\
\hline
\end{tabular}

\subsection{Comparison to zeppelin measurements}

The zeppelin measurements were taken every 3 min at different heights, while the model predictions are every $15 \mathrm{~min}$. To compare the results, the model output was interpolated to the times of the zeppelin measurement periods. Figure S8 shows the comparison between model predictions and zeppelin measurements of $N_{10}$ and $N_{100}$ (averages of 2000 points). PMCAMx-UF reproduced more than $80 \%$ of the 3 min $N_{10}$ data of zeppelin within a factor of 2 .

Figure 9 shows the predicted and observed vertical concentration profiles of particle number concentrations for $N_{10}$ and $N_{100}$, calculated for $80 \mathrm{~m}$ altitude bins, averaged over the entire PEGASOS campaign. The average profile is the result of averaging of the 3 min measurements and interpolated predictions from different flights and heights. The model showed a small tendency to underpredict $N_{10}$, especially at heights between 200 and $400 \mathrm{~m}$. PMCAMx-UF reproduced the $N_{100}$ concentration at all heights very well (except for heights between 200 and $500 \mathrm{~m}$ ). The average measured $N_{10}$ at all heights was $6050 \mathrm{~cm}^{-3}$, while the predicted concentration was equal to $5250 \mathrm{~cm}^{-3}$. The model also reproduced $75 \%$ of the $3 \mathrm{~min} N_{100}$ zeppelin measurements within a factor of 2 . The measured average $N_{100}$ at all heights was $1520 \mathrm{~cm}^{-3}$ and the extended PMCAMx-UF predicted $1380 \mathrm{~cm}^{-3}$. The ability of the revised model to reproduce the high-time-resolution zeppelin measurements reasonably well at different altitudes and locations is encouraging.

The vertical profiles shown are averages of different flights on different days and different altitudes for each flight. The number of samples at different altitudes changed for each flight, creating additional variability in the measured profiles. There are relatively few measurements at higher altitudes (above $600 \mathrm{~m}$ ) which took place in periods with relatively high concentrations, creating the apparent bump in the measurements. The model captured these high concentration periods so it predicted the same bump for the average $N_{100}$ concentration profile. This resulted in the peak at $750 \mathrm{~m}$ in Fig. 9b. The model predictions are for the same periods and the same altitudes and are the reason why the model can reproduce the apparent $N_{100}$ high concentration layer.

\subsection{Effect of SOA formation on PMCAMx-UF performance}

The results of the simulation without SOA condensation were also compared to the measurements. Including the SOA condensation reduced the NMB of $N_{10}$ by $10 \%$. The maximum decrease in $N_{10}$ due to organics condensation appeared at noon when nucleation events took place. Simulation of the secondary organics reduced the NMB of $N_{100}$ from $-40 \%$ to $-20 \%$ and the NME from $45 \%$ to $40 \%$. The organic condensation increased the average condensation sink from 

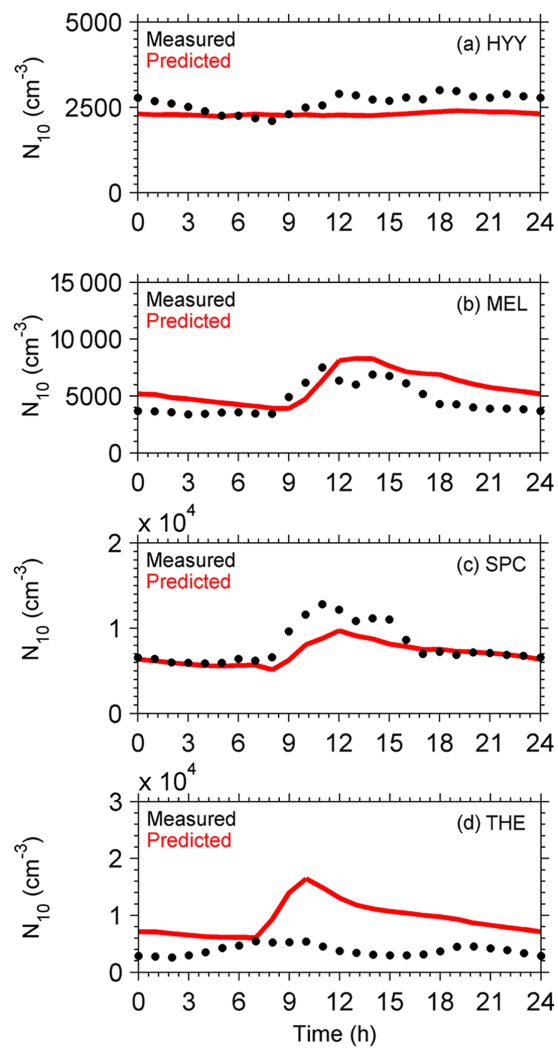

Figure 5. Average diurnal profiles of particle number concentrations $\left(\mathrm{cm}^{-3}\right.$ ) above $10 \mathrm{~nm}$ in (a) Hyytiälä (Finland), (b) Melpitz (Germany), (c) San Pietro Capofiume (Italy), and (d) Thessaloniki (Greece) during 5 June-8 July 2012. Red lines correspond to predictions and black symbols to observations.

$3.5 \times 10^{-3}$ to $4.2 \times 10^{-3} \mathrm{~s}^{-1}$. The addition of organics species decreased the average of $N_{10}$ from 6550 to $6060 \mathrm{~cm}^{-3}$ (average observed $N_{10}$ was $3910 \mathrm{~cm}^{-3}$ ) while increasing the average of $N_{100}$ from 750 to $930 \mathrm{~cm}^{-3}$ (average observed $N_{100}$ was $1080 \mathrm{~cm}^{-3}$ ) (Tables $1-3$ ).

Simulation of organics condensation improved the average predicted $N_{100}$ at all heights in the Po Valley compared to zeppelin measurements by reducing the underprediction of $N_{100}$ from $22 \%$ to $10 \%$ (Fig. S10). The model with organics reproduced the measured $N_{10}$ well at most heights, with the exception of the heights between 200 and $400 \mathrm{~m}$ (Fig. S11a). At all heights, the predicted $N_{100}$ with organics was closer to the measurements than the prediction of $N_{100}$ without organics (Fig. S11b).

\subsection{Sensitivity to boundary conditions and emissions}

The boundary conditions and emissions (gas and particles) represent potential sources of uncertainty in the particle number concentration predictions by PMCAMx-UF. Eight sensitivity simulations were conducted in which (i) PM boundary concentrations were reduced by $50 \%$, (ii) the boundary concentrations for all gases were reduced by $50 \%$, (iii) the

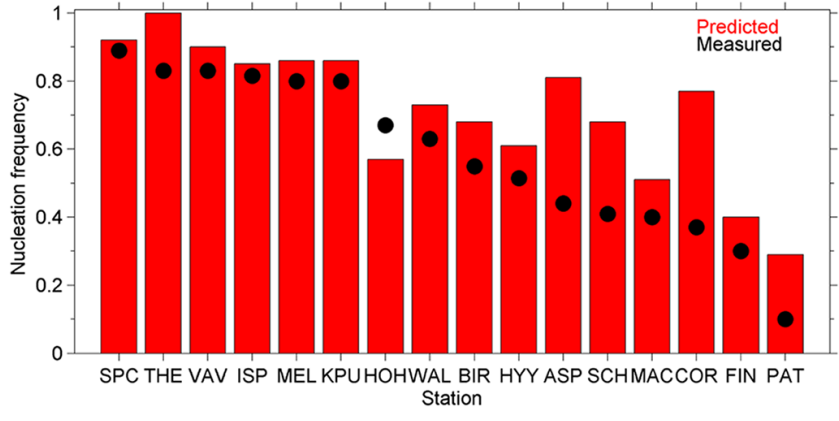

Figure 6. Predicted (red bars) vs. observed (black symbols) nucleation frequencies at the 16 measurement stations during 5 June8 July 2012.

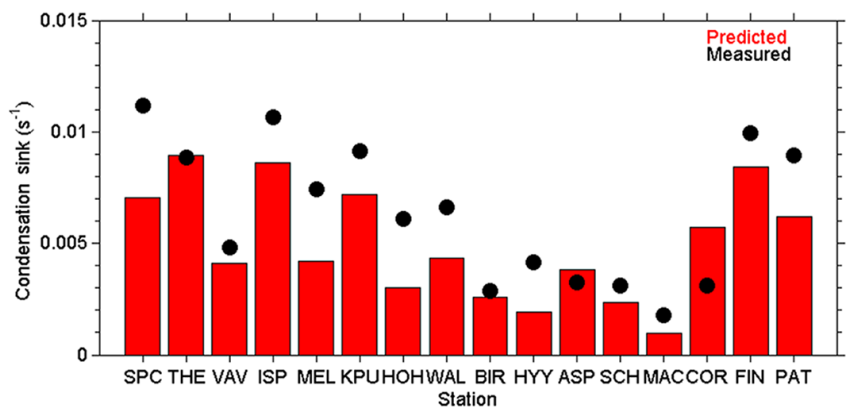

Figure 7. Predicted (red bars) vs. observed (black symbols) condensation sink at the 16 measurement stations during 5 June8 July 2012.

$\mathrm{SO}_{2}$ boundary conditions were reduced by $50 \%$, (iv) the $\mathrm{SO}_{2}$ boundary conditions were set equal to zero, (v) the PM emissions at all sizes were reduced by $50 \%$, (vi) the emissions of all gases were reduced by $50 \%$, (vii) the $\mathrm{SO}_{2}$ emissions were reduced by $50 \%$, and (viii) the $\mathrm{SO}_{2}$ emissions were set equal to zero.

Table $\mathrm{S} 7$ shows the predicted domain-average change (\%) of particle number concentrations due to these reductions in emissions and boundary conditions. The effect of the changes in boundary conditions by $50 \%$ was less than $5 \%$ for all cases, showing that the boundary conditions were not a major driver of the simulation. Conversely, the emissions of sulfur dioxide, other vapors, and particles had a major effect with changes of $10 \%-35 \%$ for corresponding $50 \%$ emission changes. Setting the sulfur dioxide emissions to zero resulted in changes of $40 \%-70 \%$ in the concentrations in the different particle size ranges, showing their importance for new particle formation and growth during this photochemically active period.

\section{Conclusions}

A new version of PMCAMx-UF was developed including the condensation of organic vapors on ultrafine particles, using 

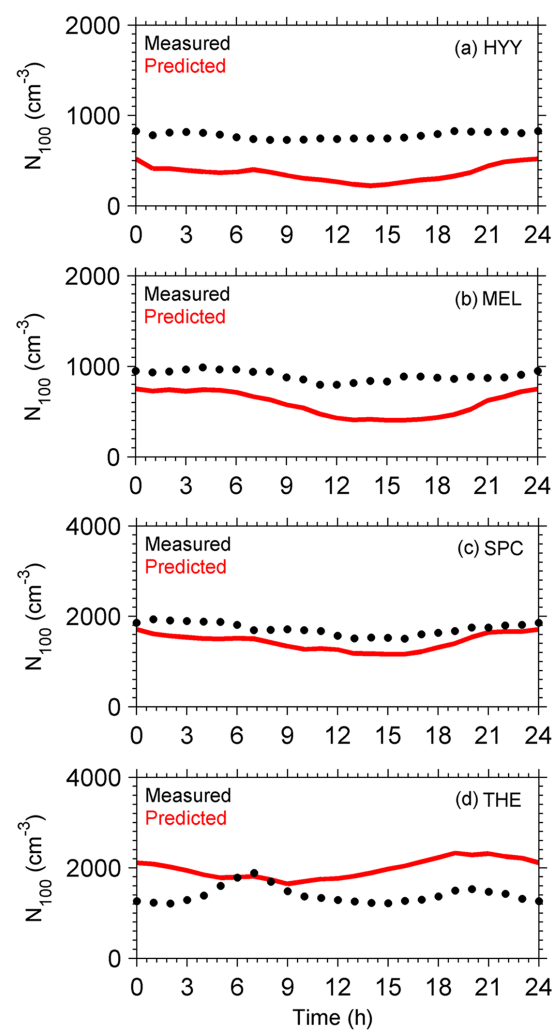

Figure 8. Average diurnal profiles of particle number concentrations $\left(\mathrm{cm}^{-3}\right.$ ) above $100 \mathrm{~nm}$ in (a) Hyytiälä (Finland), (b) Melpitz (Germany), (c) San Pietro Capofiume (Italy), and (d) Thessaloniki (Greece) during 5 June-8 July 2012. Red lines correspond to predictions and black symbols to observations.

the volatility basis set framework. We evaluated the model predictions against field observations collected in Europe for 34 days during 5 June- 8 July 2012. The measurements included both ground stations across Europe and airborne measurements from a zeppelin. The goal of this work was to better understand the effect of condensation of semi-volatile organic vapors on regional aerosol number concentration in Europe during a photochemically active period.

Including organic condensation in PMCAMx-UF improved its ability to reproduce the concentration of particles larger than $10 \mathrm{~nm}\left(N_{10}\right)$ at ground level. The inclusion of organics decreased the NMB of $N_{10}$ from $85 \%$ to $75 \%$ and the corresponding NME from $100 \%$ to $90 \%$. However, the revised model still tends to overpredict $N_{10}$ for the majority of the locations. This overprediction of $N_{10}$ is due to the overprediction of nucleation at some sites and the low number concentration of predicted preexisting particles (low condensational sink) and consistently low coagulation rate.

The $N_{100}$ predictions by PMCAMx-UF were encouraging at most sites. The NMB of $N_{100}$ was reduced from $-40 \%$ to $-20 \%$ after the addition of SOA condensation while the corresponding NME was reduced from $45 \%$ to $40 \%$. This
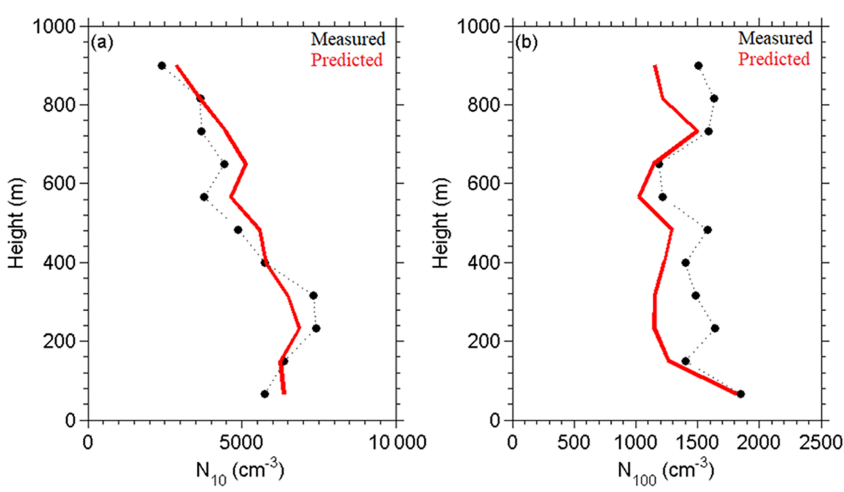

Figure 9. Comparison of predicted PMCAMx-UF (red line) vs. observed (black dots) vertical profiles of averaged particle number concentrations for (a) $N_{10}$ and (b) $N_{100}$ of 25 flights over the Po Valley during the PEGASOS campaign.

underprediction of $N_{100}$ at all sites implies the need of improvement of the size distribution of the emissions, number of preexisting particles (condensation sink), the addition of chemical aging of semi-volatile compounds, and/or the effect of extremely low-volatility organic vapors in the model (Patoulias et al., 2015).

The condensation of organics decreased the predicted $N_{10}$ concentration across Europe. The condensation of organics both grew ultrafine particles and increased the probability of collision of fresh particles with large particles (coagulation sink). This change dominated over the faster growth of the fresh particles to larger sizes in many, but not all, locations. The larger reduction of $N_{10}$ due to organic condensation $(25 \%)$ was predicted over Russia, Turkey, eastern Europe, and the Balkans. The SOA condensation increased the number of particles larger than $100 \mathrm{~nm}\left(N_{100}\right)$ at all locations. This predicted increase was more than $80 \%$ in northern Scandinavia and northern Russia.

Compared to the PEGASOS zeppelin measurements in Po Valley, PMCAMx-UF reproduced the average $N_{10}$ with an error of less than $10 \%$ and $N_{100}$ with less than $10 \%$ at all heights up to $1000 \mathrm{~m}$. The model with the condensation of organics performed better than the one without organics in reproducing the observed vertical profile of both $N_{10}$ and $N_{100}$. The model with organics reproduced more than $85 \%$ and $75 \%$ of $3 \mathrm{~min}$ data of zeppelin within a factor of 2 for $N_{10}$ and $N_{100}$, respectively.

The increase in $N_{100}$ concentrations and the decrease in $N_{10}$ concentrations in most areas due to the formation of semi-volatile organic aerosol during this photochemically active period represent two of the major insights offered by these simulations. As expected, better simulation of the formation and partitioning of organic compounds closes the gap between observations and predictions of particle number distributions. The complex role of chemical aging reactions but also LVOC and ELVOC formation (Ehn et al., 2014; Tröstl 
et al., 2016), which have been neglected in this study, will be the topic of a forthcoming publication.

Data availability. The data from this work are available upon request from Spyros Pandis (spyros@ chemeng.upatras.gr).

\section{The Supplement related to this article is available online at https://doi.org/10.5194/acp-18-13639-2018- supplement.}

Author contributions. DP conducted the simulations, analyzed the results, and wrote the paper. $\mathrm{CF}$ assisted in the development and application of PMCAMx-UF. IR contributed to the design of the study and the analysis of the results. MK and AA were responsible for the Zeppelin measurements used in this study and contributed to the evaluation of the model. SNP was responsible for the main design and coordination of the study and the synthesis of the results.

Competing interests. The authors declare that they have no conflict of interest.

Acknowledgements. We thank Markus Fiebig, Chris Lunder, Pasi Aalto, Hans Karlsson, Erik Swietlicki, Moa Sporre, JeanPhilippe Putaud, Colin O'Dowd, Ciaran Monahan, Kay Weinhold, Wolfram Birmili, Andre Sonntag, Harald Flentje, Thomas Tuch, Alfred Wiedensohler, Bourrianne Thierry, Greg Roberts, and Johannes Größ and Evangelia Kostenidou, Nikolaos Mihalopoulos, Giorgos Kouvarakis, George Biskos, and Spiridon Bezantakos for the measurements. All measurements presented here are from the Chemistry-Aerosol Mediterranean Experiment project (ChArMEx, http://charmex.1sce.ipsl.fr, last access: 12 September 2018), which is the atmospheric component of the French multidisciplinary program MISTRALS (Mediterranean Integrated STudies at Regional And Local Scales). ChArMEx France was principally funded by INSU, ADEME, ANR, CNES, CTC (Corsica region), EU/FEDER, Météo-France, and CEA. This work was funded by the ARISTEIA project (National Research Excellence 490 grant) and the ATMOPACS project (grant agreement 267099).

Edited by: Maria Kanakidou

Reviewed by: two anonymous referees

\section{References}

Adams, P. J. and Seinfeld, J. H.: Predicting global aerosol size distributions in general circulation models, J. Geophys. Res., 107, 4370, https://doi.org/10.1029/2001JD001010, 2002.

Anttila, T. and Kerminen, V.: Condensational growth of atmospheric nuclei by organic vapours, J. Aerosol Sci., 34, 41-61, 2003.

Argueso, D., Hidalgo-Munoz, J. M., Gamiz-Fortis, S. R., and Esteban-Parra, M. J.: Evaluation of WRF parameterizations for climate studies over Southern Spain using a multistep regionalization, J. Climate, 24, 5633-5651, 2011.

Baranizadeh, E., Murphy, B. N., Julin, J., Falahat, S., Reddington, C. L., Arola, A., Ahlm, L., Mikkonen, S., Fountoukis, C., Patoulias, D., Minikin, A., Hamburger, T., Laaksonen, A., Pandis, S. N., Vehkamäki, H., Lehtinen, K. E. J., and Riipinen, I.: Implementation of state-of-the-art ternary new-particle formation scheme to the regional chemical transport model PMCAMx-UF in Europe, Geosci. Model Dev., 9, 2741-2754, https://doi.org/10.5194/gmd-9-2741-2016, 2016.

Carter, W. P. L.: Programs and files implementing the SAPRC99 mechanism and its associates emissions processing procedures for Models-3 and other regional models, available at: www. engr.ucr.edu/ carter/pubs/s99mod3.pdf (last access: 12 September 2018), 2000

Dal Maso, M., Kulmala, M., Riipinen, I., Wagner, R., Hussein, T., Aalto, P., and Lehtinen, K. E. J.: Formation and growth of fresh atmospheric aerosols: eight years of aerosol size distribution data from SMEAR II, Hyytiälä, Finland, Boreal Environ. Res., 10, 323-336, 2005.

de Meij, A., Gzella, A., Cuvelier, C., Thunis, P., Bessagnet, B., Vinuesa, J. F., Menut, L., and Kelder, H. M.: The impact of MM5 and WRF meteorology over complex terrain on CHIMERE model calculations, Atmos. Chem. Phys., 9, 66116632, https://doi.org/10.5194/acp-9-6611-2009, 2009.

Denier van der Gon, H. A. C., Visschedijk, A. J. H., Johansson, C., Hedberg Larsson, E., Harrison, R., and Beddows, D.: Size resolved pan European anthropogenic particle number inventory, EUCAARI Deliverable report D141 (available on request from EUCAARI project office), TNO, the Netherlands, 2009

Donahue, N. M., Robinson, A. L., Stanier, C. O., and Pandis, S. N.: Coupled partitioning, dilution, and chemical aging of semivolatile organics, Environ. Sci. Technol., 40, 2635-2643, 2006.

Ehn, M., Thornton, J. A., Kleist, E., Sipilä, M., Junninen, H., Pullinen, I., Springer, M., Rubach, F., Tillmann, R., Lee, B., LopezHilfiker, F., Andres, S., Acir, I. H., Rissanen, M., Jokinen, T., Schobesberger, S., Kangasluoma, J., Kontkanen, J., Nieminen, T., Kurtén, T., Nielsen, L. B., Jørgensen, S., Kjaergaard, H. G., Canagaratna, M., Dal Maso, M., Berndt, T., Petäjä, T., Wahner, A., Kerminen, V. M., Kulmala, M., Worsnop, D. R., Wildt, J., and Mentel, T. F.: A large source of low-volatility secondary organic aerosol, Nature, 506, 476-479, 2014.

Eisele, F. L. and McMurry, P. H.: Recent progress in understanding particle nucleation and growth, Philos. T. R. Soc. Lond., 352, 191-201, 1997.

Environ: User's guide to the comprehensive air quality model with extensions (CAMx), version 4.02, report, ENVIRON Int. Corp., Novato, CA, 2003.

Fountoukis, C., Racherla, P. N., Denier van der Gon, H. A. C., Polymeneas, P., Charalampidis, P. E., Pilinis, C., Wiedensohler, A., Dall'Osto, M., O'Dowd, C., and Pandis, S. N.: Evaluation of a three-dimensional chemical transport model (PMCAMx) in the European domain during the EUCAARI May 2008 campaign, Atmos. Chem. Phys., 11, 10331-10347, https://doi.org/10.5194/acp-11-10331-2011, 2011.

Fountoukis, C., Riipinen, I., Denier van der Gon, H. A. C., Charalampidis, P. E., Pilinis, C., Wiedensohler, A., O’Dowd, C., Putaud, J. P., Moerman, M., and Pandis, S. N.: Simulating ul- 
trafine particle formation in Europe using a regional CTM: contribution of primary emissions versus secondary formation to aerosol number concentrations, Atmos. Chem. Phys., 12, 86638677, https://doi.org/10.5194/acp-12-8663-2012, 2012.

Fountoukis, C., Megaritis, A. G., Skyllakou, K., Charalampidis, P. E., Pilinis, C., Denier van der Gon, H. A. C., Crippa, M., Canonaco, F., Mohr, C., Prévôt, A. S. H., Allan, J. D., Poulain, L., Petäjä, T., Tiitta, P., Carbone, S., Kiendler-Scharr, A., Nemitz, E., O’Dowd, C., Swietlicki, E., and Pandis, S. N.: Organic aerosol concentration and composition over Europe: insights from comparison of regional model predictions with aerosol mass spectrometer factor analysis, Atmos. Chem. Phys., 14, 9061-9076, https://doi.org/10.5194/acp-14-9061-2014, 2014.

Garcia-Diez, M., Fernandez, J., Fita, L., and Yague, C.: Seasonal dependence of WRF model biases and sensitivity to PBL schemes over Europe, Q. J. Roy. Meteor. Soc., 139, 501-514, 2012.

Gaydos, T., Pinder, R., Koo, B., Fahey, K., Yarwood, G., and Pandis, S. N.: Development and application of a three-dimensional Chemical Transport Model, PMCAMx, Atmos. Environ., 41, 2594-2611, 2007.

Gaydos, T. M., Stainer, C. O., and Pandis, S. N.: Modeling of insitu ultrafine atmospheric particle formation in the eastern United State, J. Geophys. Res., 110, D07S12, https://doi.org/10.1029/2004JD004683, 2005.

Goldstein, A. H. and Galbally, I. E.: Known and unexplored organic constituents in the earth's atmosphere, Environ. Sci. Technol., 41, 1514-1521, 2007.

Guenther, A., Karl, T., Harley, P., Wiedinmyer, C., Palmer, P. I., and Geron, C.: Estimates of global terrestrial isoprene emissions using MEGAN (Model of Emissions of Gases and Aerosols from Nature), Atmos. Chem. Phys., 6, 3181-3210, https://doi.org/10.5194/acp-6-3181-2006, 2006.

Hallquist, M., Wenger, J. C., Baltensperger, U., Rudich, Y., Simpson, D., Claeys, M., Dommen, J., Donahue, N. M., George, C., Goldstein, A. H., Hamilton, J. F., Herrmann, H., Hoffmann, T., Iinuma, Y., Jang, M., Jenkin, M. E., Jimenez, J. L., Kiendler-Scharr, A., Maenhaut, W., McFiggans, G., Mentel, Th. F., Monod, A., Prévôt, A. S. H., Seinfeld, J. H., Surratt, J. D., Szmigielski, R., and Wildt, J.: The formation, properties and impact of secondary organic aerosol: current and emerging issues, Atmos. Chem. Phys., 9, 5155-5236, https://doi.org/10.5194/acp9-5155-2009, 2009.

Hamed, A., Joutsensaari, J., Mikkonen, S., Sogacheva, L., Dal Maso, M., Kulmala, M., Cavalli, F., Fuzzi, S., Facchini, M. C., Decesari, S., Mircea, M., Lehtinen, K. E. J., and Laaksonen, A.: Nucleation and growth of new particles in Po Valley, Italy, Atmos. Chem. Phys., 7, 355-376, https://doi.org/10.5194/acp-7355-2007, 2007.

Im, U., Markakis, K., Unal, A., Kindap, T., Poupkou, A., Incecik, S., Yenigun, O., Melas, D., Theodosi, C., and Mihalopoulos, N.: Study of a winter PM episode in Istanbul using the high resolution WRF/CMAQ modeling system, Atmos. Environ., 44, 30853094, 2010.

Jimenez, J. L., Canagaratna, M. R., Donahue, N. M., Prevot, A. S. H., Zhang, Q., Kroll, J. H., DeCarlo, P. F., Allan, J. D., Coe, H., Ng, N. L., Aiken, A. C., Docherty, K. S., Ulbrich, I. M., Grieshop, A. P., Robinson, A. L., Duplissy, J., Smith, J. D., Wilson, K. R., Lanz, V. A., Hueglin, C., Sun, Y. L., Tian, J., Laak- sonen, A., Raatikainen, T., Rautiainen, J., Vaattovaara, P., Ehn, M., Kulmala, M., Tomlinson, J. M., Collins, D. R., Cubison, M. J., E, Dunlea, J., Huffman, J. A., Onasch, T. B., Alfarra, M. R., Williams, P. I., Bower, K., Kondo, Y., Schneider, J., Drewnick, F., Borrmann, S., Weimer, S., Demerjian, K., Salcedo, D., Cottrell, L., Griffin, R., Takami, A., Miyoshi, T., Hatakeyama, S., Shimono, A., Sun, J. Y., Zhang, Y. M., Dzepina, K., Kimmel, J. R., Sueper, D., Jayne, J. T., Herndon, S. C., Trimborn, A. M., Williams, L. R., Wood, E. C., Middlebrook, A. M., Kolb, C. E., Baltensperger, U., and Worsnop, D. R.: Evolution of organic aerosols in the atmosphere, Science, 326, 1525-1529, 2009.

Jimenez-Guerrero, P., Jorba, O., Baldasano, J. M., and Gasso, S.: The use of a modelling system as a tool for air quality management: Annual high-resolution simulations and evaluation, Sci. Total Environ., 390, 323-340, 2008.

Jung, J., Adams, P. J., and Pandis, S. N.: Simulating the size distribution and chemical composition of ultrafine particles during nucleation events, Atmos. Environ., 40, 2248-2259, 2006.

Jung, J., Adams, P. J., and Pandis, S. N.: Evaluation of nucleation theories in a sulfur-rich environment, Aerosol Sci. Tech., 42, 495-504, 2008.

Jung, J., Fountoukis, C., Adams, P. J., and Pandis, S. N.: Simulation of in situ ultrafine particle formation in the eastern United States using PMCAMx-UF, J. Geophys. Res., 115, D03203, https://doi.org/10.1029/2009JD012313, 2010.

Kanakidou, M., Seinfeld, J. H., Pandis, S. N., Barnes, I., Dentener, F. J., Facchini, M. C., Van Dingenen, R., Ervens, B., Nenes, A., Nielsen, C. J., Swietlicki, E., Putaud, J. P., Balkanski, Y., Fuzzi, S., Horth, J., Moortgat, G. K., Winterhalter, R., Myhre, C. E. L., Tsigaridis, K., Vignati, E., Stephanou, E. G., and Wilson, J.: Organic aerosol and global climate modelling: a review, Atmos. Chem. Phys., 5, 1053-1123, https://doi.org/10.5194/acp-5-10532005, 2005.

Karydis, V. A., Tsimpidi, A. P., and Pandis, S. N.: Evaluation of a three-dimensional chemical transport model (PMCAMx) in the eastern United States for all four seasons, J. Geophys. Res., 112, D14211, https://doi.org/10.1029/2006JD007890, 2007.

Kerminen, V.-M., Virkkula, A., Hillamo, R., Wexler, A. S., and Kulmala, M.: Secondary organics and atmospheric cloud condensation nuclei production, J. Geophys. Res., 105, 9255-9264, 2000.

Kerminen, V.-M., Paramonov, M., Anttila, T., Riipinen, I., Fountoukis, C., Korhonen, H., Asmi, E., Laakso, L., Lihavainen, H., Swietlicki, E., Svenningsson, B., Asmi, A., Pandis, S. N., Kulmala, M., and Petäjä, T.: Cloud condensation nuclei production associated with atmospheric nucleation: a synthesis based on existing literature and new results, Atmos. Chem. Phys., 12, 12037 12059, https://doi.org/10.5194/acp-12-12037-2012, 2012.

Kulmala, M., Toivonen, A., Makela, J. M., and Laaksonen A.: Analysis of the growth of nucleation mode particles observed in Boreal forest, Tellus B, 50, 449-462, 1998.

Kulmala, M., Pirjola, L., Makela, J. M.: Stable sulphate clusters as a source of new atmospheric particles, Nature, 404, 66-69, 2000.

Kulmala, M., Vehkamaki, H., Petaja, T., Dal Maso, M., Lauri, A., Kerminen, V.-M., Birmili, W., and McMurry, P. H.: Formation and growth of ultrafine atmospheric particles: A review of observations, J. Aerosol Sci., 35, 143-176, 2004.

Kulmala, M., Asmi, A., Lappalainen, H. K., Baltensperger, U., Brenguier, J.-L., Facchini, M. C., Hansson, H.-C., Hov, Ø., O’Dowd, C. D., Pöschl, U., Wiedensohler, A., Boers, R., 
Boucher, O., de Leeuw, G., Denier van der Gon, H. A. C., Feichter, J., Krejci, R., Laj, P., Lihavainen, H., Lohmann, U., McFiggans, G., Mentel, T., Pilinis, C., Riipinen, I., Schulz, M., Stohl, A., Swietlicki, E., Vignati, E., Alves, C., Amann, M., Ammann, M., Arabas, S., Artaxo, P., Baars, H., Beddows, D. C. S., Bergström, R., Beukes, J. P., Bilde, M., Burkhart, J. F., Canonaco, F., Clegg, S. L., Coe, H., Crumeyrolle, S., D'Anna, B., Decesari, S., Gilardoni, S., Fischer, M., Fjaeraa, A. M., Fountoukis, C., George, C., Gomes, L., Halloran, P., Hamburger, T., Harrison, R. M., Herrmann, H., Hoffmann, T., Hoose, C., Hu, M., Hyvärinen, A., Hõrrak, U., Iinuma, Y., Iversen, T., Josipovic, M., Kanakidou, M., Kiendler-Scharr, A., Kirkevåg, A., Kiss, G., Klimont, Z., Kolmonen, P., Komppula, M., Kristjánsson, J.-E., Laakso, L., Laaksonen, A., Labonnote, L., Lanz, V. A., Lehtinen, K. E. J., Rizzo, L. V., Makkonen, R., Manninen, H. E., McMeeking, G., Merikanto, J., Minikin, A., Mirme, S., Morgan, W. T., Nemitz, E., O’Donnell, D., Panwar, T. S., Pawlowska, H., Petzold, A., Pienaar, J. J., Pio, C., Plass-Duelmer, C., Prévôt, A. S. H., Pryor, S., Reddington, C. L., Roberts, G., Rosenfeld, D., Schwarz, J., Seland, Ø., Sellegri, K., Shen, X. J., Shiraiwa, M., Siebert, H., Sierau, B., Simpson, D., Sun, J. Y., Topping, D., Tunved, P., Vaattovaara, P., Vakkari, V., Veefkind, J. P., Visschedijk, A., Vuollekoski, H., Vuolo, R., Wehner, B., Wildt, J., Woodward, S., Worsnop, D. R., van Zadelhoff, G.J., Zardini, A. A., Zhang, K., van Zyl, P. G., Kerminen, V.M., S Carslaw, K., and Pandis, S. N.: General overview: European Integrated project on Aerosol Cloud Climate and Air Quality interactions (EUCAARI) - integrating aerosol research from nano to global scales, Atmos. Chem. Phys., 11, 13061-13143, https://doi.org/10.5194/acp-11-13061-2011, 2011.

Laakso, L., Makela, J. M., Pirjola, L., and Kulmala, M.: Model studies on ion - induced nucleation in the atmosphere, J. Geophys. Res., 107, 4427, https://doi.org/10.1029/2002JD002140, 2002.

Lane, T. E., Donahue, N. M., and Pandis, S. N.: Simulating secondary organic aerosol formation using the volatility basis-set approach in a chemical transport model, Atmos. Environ., 42, 7439-7451, 2008a.

Lane, T. E., Donahue, N. M., Pandis, S. N.: Effect of $\mathrm{NO}_{x}$ on secondary organic aerosol concentrations, Environ. Sci. Technol., 42, 6022-6027, 2008b.

Makkonen, R., Asmi, A., Korhonen, H., Kokkola, H., Järvenoja, S., Räisänen, P., Lehtinen, K. E. J., Laaksonen, A., Kerminen, V.M., Järvinen, H., Lohmann, U., Bennartz, R., Feichter, J., and Kulmala, M.: Sensitivity of aerosol concentrations and cloud properties to nucleation and secondary organic distribution in ECHAM5-HAM global circulation model, Atmos. Chem. Phys., 9, 1747-1766, https://doi.org/10.5194/acp-9-1747-2009, 2009.

Merikanto, J., Spracklen, D. V., Mann, G. W., Pickering, S. J., and Carslaw, K. S.: Impact of nucleation on global CCN, Atmos. Chem. Phys., 9, 8601-8616, https://doi.org/10.5194/acp-9-86012009, 2009.

Murphy, B. N. and Pandis, S. N.: Simulating the formation of semivolatile primary and secondary organic aerosol in a regional chemical transport model, Environ. Sci. Technol., 43, 47224728, 2009.

Napari, I., Noppel, M., Vehkamaki, H., and Kulmala, M.: Parameterization of ternary nucleation rates for $\mathrm{H}_{2} \mathrm{SO}_{4}-\mathrm{NH}_{3}$ $\mathrm{H}_{2} \mathrm{O}$ vapors, J. Geophys. Res., 107, AAC 6-1-AAC 6-6, https://doi.org/10.1029/2002JD002132, 2002.
Nenes, A., Pandis, S. N., and Pilinis, C.: ISORROPIA: a new thermodynamic equilibrium model for multiphase multicomponent inorganic aerosols, Aquat. Geochem., 4, 123-152, 1998.

O’Dowd, C. D., Langmann, B., Varghese, S., Scannell, C., Ceburnis, D., and Facchini, M. C.: A combined organic-inorganic sea-spray source function, Geophys. Res. Lett., 35, L01801, https://doi.org/10.1029/2007GL030331, 2008.

Pandis, S. N., Wexler, A. S., and Seinfeld, J. H.: Secondary organic aerosol formation and transport. 2. Predicting the ambient secondary organic aerosol size distribution, Atmos. Environ. AGen., 27, 2403-2416, 1993.

Pathak, R. K., Presto, A. A., Lane, T. E., Stanier, C. O., Donahue, N. M., Pandis, S. N.: Ozonolysis of a-pinene: parameterization of secondary organic aerosol mass fraction, Atmos. Chem. Phys., 7, 3811-3821, 2007

Patoulias, D., Fountoukis, C., Riipinen, I., and Pandis, S. N.: The role of organic condensation on ultrafine particle growth during nucleation events, Atmos. Chem. Phys., 15, 6337-6350, https://doi.org/10.5194/acp-15-6337-2015, 2015.

Pierce, J. R. and Adams, P. J.: A computationally efficient aerosol nucleation/condensation method: Pseudo-steady state sulfuric acid, Aerosol Sci. Tech., 43, 216-226, 2009.

Pirjola, L. and Kulmala, M.: Development of particle size and composition distributions with a novel aerosol dynamics model, Tellus B, 53, 491-509, 2001.

Riipinen, I., Pierce, J. R., Yli-Juuti, T., Nieminen, T., Häkkinen, S., Ehn, M., Junninen, H., Lehtipalo, K., Petäjä, T., Slowik, J., Chang, R., Shantz, N. C., Abbatt, J., Leaitch, W. R., Kerminen, V.-M., Worsnop, D. R., Pandis, S. N., Donahue, N. M., and Kulmala, M.: Organic condensation: a vital link connecting aerosol formation to cloud condensation nuclei (CCN) concentrations, Atmos. Chem. Phys., 11, 3865-3878, https://doi.org/10.5194/acp-11-3865-2011, 2011.

Russell, L. M.: Aerosol organic-mass-to-organic-carbon ratio measurements, Environ. Sci. Technol., 37, 2982-2987, https://doi.org/10.1021/Es026123w, 2003.

Skamarock, W. C., Klemp, J. B., Dudhia, J., Gill, D. O., Barker, D. M., Wang,W., and Powers, J. G.: A Description of the Advanced Research WRF Version 2, NCAR Technical Note, available at: http://www2.mmm.ucar.edu/wrf/users/docs/arw_v2_070111. pdf (last access: 12 September 2018), 2005.

Sofiev, M., Vankevich, R., Lanne, M., Koskinen, J., and Kukkonen, J.: On integration of a Fire Assimilation System and a chemical transport model for near-real-time monitoring of the impact of wild-land fires on atmospheric composition and air quality, Modelling, Monitoring and Management of Forest Fires, WIT Trans. Ecol. Envir., 119, 343-351, 2008a.

Sofiev, M., Lanne, M., Vankevich, R., Prank, M., Karppinen, A., and Kukkonen, J.: Impact of wild-land fires on European air quality in 2006-2008, Modelling, Monitoring and Management of Forest Fires, WIT Trans. Ecol. Envir., 119, 353-361, 2008b.

Sogacheva, L., Hamed, A., Facchini, M. C., Kulmala, M., and Laaksonen, A.: Relation of air mass history to nucleation events in Po Valley, Italy, using back trajectories analysis, Atmos. Chem. Phys., 7, 839-853, https://doi.org/10.5194/acp-7-8392007, 2007.

Stanier, C. O., Khlystov, A. Y., and Pandis, S. N.: Nucleation events during the Pittsburgh Air Quality Study: Description and rela- 
tion to key meteorological, gas phase, and aerosol parameters, Aerosol Sci. Tech., 38S, 253-264, 2004.

Stanier, C. O., Pathak, R. K., and Pandis, S. N.: Measurements of the volatility of aerosols from $\alpha$-pinene ozonolysis, Environ. Sci. Technol., 41, 2756-2763, 2007.

Tröstl, J., Chuang, W. K., Gordon, H., Heinritzi, M., Yan, C., Molteni, U., Ahlm, L., Frege, C., Bianchi, F., Wagner, R., Simon, M., Lehtipalo, K., Williamson, C., Craven, J. S., Duplissy, J., Adamov, A., Almeida, J., Bernhammer, A.-K., Breitenlechner, M., Brilke, S., Dias, A., Ehrhart, S., Flagan, R. C., Franchin, A., Fuchs, C., Guida, R., Gysel, M., Hansel, A., Hoyle, C. R., Jokinen, T., Junninen, H., Kangasluoma, J., Keskinen, H., Kim, J., Krapf, M., Kürten, A., Laaksonen, A., Lawler, M., Leiminger, M., Mathot, S., Möhler, O., Nieminen, T., Onnela, A., Petäjä, T., Piel, F. M., Miettinen, P., Rissanen, M. P., Rondo, L., Sarnela, N., Schobesberger, S., Sengupta, K., Sipilä, M., Smith, J. N., Steiner, G., Tomè, A., Virtanen, A., Wagner, A. C., Weingartner, E., Wimmer, D., Winkler, P. M., Ye, P. L., Carslaw, K. S., Curtius, J., Dommen, J., Kirkby, J., Kulmala, M., Riipinen, I., Worsnop, D. R., Donahue, N. M., and Baltensperger, U.: The role of low-volatility organic compounds in initial particle growth in the atmosphere, Nature, 533, 527-531, 2016.

Tsimpidi, A. P., Karydis, V. A., Zavala, M., Lei, W., Molina, L., Ulbrich, I. M., Jimenez, J. L., and Pandis, S. N.: Evaluation of the volatility basis-set approach for the simulation of organic aerosol formation in the Mexico City metropolitan area, Atmos. Chem. Phys., 10, 525-546, https://doi.org/10.5194/acp-10-5252010, 2010.

Tzivion, S., Feingold, G., and Levin, Z.: An efficient numerical solution to the stochastic collection equation, J. Atmos. Sci., 44, 3139-3149, 1987.

Tzivion, S., Feingold, G., and Levin, Z.: The evolution of raindrop spectra. Part II: collisional collection/breakup and evaporation in a rain shaft, J. Atmos. Sci., 46, 3312-3327, 1989.
Vehkamäki, H., Kulmala, M., Napari, I., Lehtinen, K. E. J., Timmreck, C., Noppel, M., and Laaksonen, A.: An improved parameterization for sulfuric acid-water nucleation rates for tropospheric and stratospheric conditions, J. Geophys. Res., 107, 4622-4632, 2002.

Visschedijk, A. J. H., Zandveld, P., and Denier van der Gon, H. A. C.: TNO Report 2007 A-R0233/B: A high resolution gridded European emission database for the EU integrated project GEMS, Organization for Applied Scientific Research, the Netherlands, 2007.

Wang, M. and Penner, J. E.: Aerosol indirect forcing in a global model with particle nucleation, Atmos. Chem. Phys., 9, 239-260, https://doi.org/10.5194/acp-9-239-2009, 2009.

Weber, R. J., McMurry, P. H., Mauldin, L., Tanner, D. J., Eisele, F. L., Brechtel, F. J., Kreidenweis, S. M., Kok, G. L., Schillawski, R. D., and Baumgardner, D.: A study of new particle formation and growth involving biogenic and trace gas species measured during ACE 1, J. Geophys. Res., 103, 16385-16396, 1998.

Weber, R. J., McMurry, P. H., Mauldin III, R. L., Tanner, D. J., Eisele, F. L., Clarke, A. D., and Kapustin, V. N.: New particle formation in the remote troposphere: a comparison of observations at various sites, Geophys. Res. Lett., 26, 307-310, 1999.

Yu, F. and Luo, G.: Simulation of particle size distribution with a global aerosol model: contribution of nucleation to aerosol and CCN number concentrations, Atmos. Chem. Phys., 9, 76917710, https://doi.org/10.5194/acp-9-7691-2009, 2009.

Yue, D. L., Hu, M., Zhang, R. Y., Wang, Z. B., Zheng, J., Wu, Z. J., Wiedensohler, A., He, L. Y., Huang, X. F., and Zhu, T.: The roles of sulfuric acid in new particle formation and growth in the mega-city of Beijing, Atmos. Chem. Phys., 10, 4953-4960, https://doi.org/10.5194/acp-10-4953-2010, 2010.

Zhang, K. M. and Wexler, A. S.: A hypothesis for condensation of fresh atmospheric nuclei, J. Geophys. Res., 107, 4577, https://doi.org/10.1029/2002JD002180, 2002. 